\title{
Robust Capital Regulation
}

\author{
Viral Acharya, Hamid Mehran, Til Schuermann, \\ and Anjan Thakor
}

\begin{abstract}
Regulators and markets can find the balance sheets of large financial institutions difficult to penetrate, and they are mindful of how undercapitalization can create incentives to take on excessive risk. This study proposes a novel framework for capital regulation that addresses banks' incentives to take on excessive risk and leverage. The framework consists of a special capital account in addition to a core capital requirement. The special account would accrue to a bank's shareholders as long as the bank is solvent, but would pass to the bank's regulators - rather than its creditors - if the bank fails. By design, this special account thus limits risk taking, but ensures that creditors' disciplining incentives are preserved.
\end{abstract}

In early 2009, the largest U.S. bank holding companies, including the nineteen that would undergo federally mandated stress tests later that year, were all considered adequately capitalized according to government regulatory standards. The market, however, had a different view: At the time, most of those institutions were trading at less than book value and all were at or near record highs for their credit default swap spreads - an indicator of a company's likelihood of default. Indeed, some of them might have failed in fall 2008 had there not been a systemwide capital injection by the government.

For the regulators and the markets, it was difficult to penetrate the balance sheets of those financial institutions, let alone assess which ones needed additional capital, the amount required, and the cost of that capital. The bank stress test in 2009 offered some temporary clarity, at least in regard to the nineteen participating institutions, and its success prompted Congress to enshrine stress testing in the law with the Dodd-Frank Wall Street Reform and Consumer Protection Act. In fact, the most recent round of stress tests covered thirty institutions. Nonetheless, we continue to grapple with the broader questions of financial fragility and capital adequacy. ${ }^{1}$

In this edition of Current Issues, we provide a fresh perspective on the forces that shape banks' capital structure choices, showing how these choices are distorted by regulatory safety nets that give banks incentives to take on excessive risk and leverage. To address the negative aspects of these incentives, specifically the privatization of banks' profits and the socialization of their losses, we offer a novel approach to capital regulation. Our proposal involves a two-part capital requirement: a core capital requirement (much like existing requirements) and a special capital account requirement.

\footnotetext{
${ }^{1}$ The 2009 stress test is more formally known as the Supervisory Capital Assessment Program, or SCAP, while the recent incarnation is called the Comprehensive Capital Analysis and Review (or CCAR, for the original nineteen banks) and Capital Analysis and Review (or CapPR, for eleven banks with more than $\$ 50$ billion in assets). For more information on SCAP, see http://www.federalreserve.gov/newsevents/ press/bcreg/20090507a.htm; on CCAR and CapPR, see http://www.federalreserve.gov/newsevents/press/ bcreg/20120313a.htm.
} 
The special account would involve capital that must be invested in Treasury securities or their equivalents. The assets segregated in the special account would accrue to the bank's shareholders as long as the bank is solvent and to the regulators, rather than the creditors, if the bank fails.

The basic idea, formally developed in Acharya, Mehran, and Thakor (2010), is to exploit the role of equity in reducing the risk appetite of banks by requiring them to hold additional capital as well as the role of uninsured debt in encouraging the monitoring of bank management by ensuring that creditors have enough "skin in the game" to find such monitoring desirable.

The Treasury securities in the special capital account could be used by regulators to support the financial system if it is threatened by failing banks. For instance, the securities could be used to reduce the banks' cost of lending to households and the real sector, or they could be saved as a cushion for future crises.

In addition, the quantification of the capital requirement need not depend exclusively on the use of historical data for calibration of the bank's risks; instead, it would rely on several different approaches, such as market-based signals of bank-level and systemic risk as well as regulatory intelligence gathered through periodic stress tests of the financial sector. Besides being "robust" in the sense of calibration, our proposal is also robust in the sense that it does not rely solely on bank equity to provide the right incentives; it also recognizes market discipline provided by uninsured creditors.

\section{The Capital Structure Decision}

How does any firm decide on its capital structure? In other words, how much equity, and debt, should it use? And why might the answer be different for a bank than for a nonfinancial firm? In particular, why do banks tend to have such high levels of debt?

A typical nonfinancial firm has equity (capital) that exceeds 50 percent of its assets. Chart 1 shows the ratios of equity to assets-also called capital ratios - for 5,988 firms across a broad range of sectors at year-end 2009. Credit intermediaries have by far the lowest capital ratio, at 12.1 percent, less than half the capital of the next sector, insurance, at 29 percent, which itself is less than half the ratio for most nonfinancial sectors. ${ }^{2}$

Academic studies of corporate finance entered the debate with Modigliani and Miller's famous (1958) "leverage indifference" theorem, and the debate has been reinvigorated with contributions by Mehran and Thakor (2011) and Admati et al. (2010). In a world without frictions (no taxes, no bankruptcy costs, no safety net, such as a lender of last resort or a deposit insurer), Modigliani and Miller show that the capital structure decision - that is, the decision on how to finance the balance sheet-for a given size of firm and a given asset portfolio composition matters only if it

\footnotetext{
${ }^{2}$ Credit intermediaries are depository institutions and nondepository credit institutions.
}

Chart 1

\section{Capital Ratios by Sector: Year-End 2009}

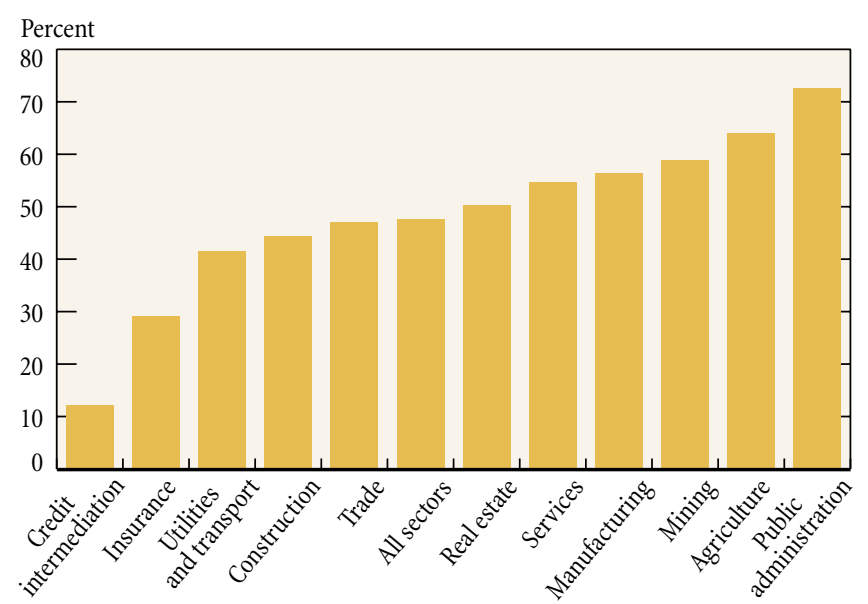

Source: Compustat.

Notes: Equity is the residual of total (book) assets less total (book) liabilities. Firms in the sample total 5,988.

affects the value of the firm. Their argument takes the balance sheet and thus the investment decisions that formed the balance sheet (projects, machines, buildings, or, in the case of a bank, loans made or securities bought) as given, implying that the financing mix decision is separate from the firm's investment decision.

The real world, of course, looks quite different from the one created by Modigliani and Miller, particularly for banks. It has been argued that banks tend to be highly levered because the conditions imposed by Modigliani and Miller do not apply to them. And indeed, a number of reasons have been cited to support this view.

The standard argument against applying the Modigliani and Miller theorem is that deposits are a factor of production in banking: Banks not only use deposits to make loans, the institutions also provide liquidity and transaction services to depositors. As a result, we should expect banks to be highly levered, since deposits are a form of debt. However, given the constrained supply of core deposits, it is not obvious why banks cannot add large amounts of equity to whatever deposits they gather, which would then make it difficult to explain the paucity of equity in banking.

A second popular argument is that banks prefer high leverage because interest payments on debt are tax deductible while shareholder dividends are not. This statement is true, but it cannot explain why banks are more levered than nonfinancial firms that enjoy the same debt tax shield.

A third argument, one that we generally favor, has appeared in theories that emphasize the monitoring and disciplining role of leverage. As debt increases, the loss-absorption capacity provided by equity capital in the event of bankruptcy shrinks, inducing 
creditors to monitor the activities of management more closely and to raise the price of debt to compensate for the increased risk.

This effect is present for all firms, but bank funding appears to be unique because it is a liability that comes in the form of demand deposits. Calomiris and Kahn (1991) were the first to note that uninsured depositors who monitor the bank can decide to withdraw their deposits if they come to suspect managerial inefficiency or fraud. Observing these withdrawals, uninformed depositors may follow suit. Their action precipitates a full-scale bank run that may force liquidation of the institution. So fear of such a run can induce the bank's management to stay on the straight and narrow.

\section{Although the disciplining role of debt can help reduce certain agency costs in banks, it can also have deleterious consequences.}

In this framework, leverage is needed in order for market discipline to control agency problems. ${ }^{3}$ The effect extends beyond deposits, however. As borrower (or, in this case, bank) risk increases, lenders tend to shorten maturities when the option of not renewing the debt becomes more valuable. Indeed, such maturity shortening was in broad evidence throughout the financial crisis.

Since this line of reasoning is meant to justify the heavy use of demandable debt by banks, the potential discipline imposed by such debt is substantial (at least in theory), because the bank can be shut down very quickly by creditors who refuse to roll over debt. To explain why nonfinancial firms, which also stand to benefit from the disciplining role of leverage, do not use this form of debt, one must invoke the argument that the potential for agency problems, and hence the need for market discipline, is much greater in banking than in nonfinancial firms. The greater ease with which banks can change their asset mix and keep it hidden from all but the most diligent and skilled monitors is likely an important reason.

The recent financial crisis has in fact provided many examples of creative manufacturing of assets whose "tail risks" were far from transparent, even to some insiders. As the riskiness of those assets became apparent to outsiders, the market reacted quickly by either shortening the maturity of credit or refusing to roll it over altogether.

\footnotetext{
${ }^{3}$ See Diamond and Rajan $(2000,2001)$, who justify demandable bank debt given the inability of bankers to pledge their relationship-specific rents to depositors. Some (for example, Admati et al. [2010]) contend that the market discipline argument in favor of bank leverage has been overstated, and that the cost of bank equity is not as high as many have asserted. While it is true that, in many cases, creditors may have been ineffective in disciplining banks during this crisis, we believe it is because their incentives to do so were diluted by the de facto protection afforded to them by the regulatory safety net.
}

Although the disciplining role of debt can help reduce certain agency costs in banks, it can also have deleterious consequences. Jensen and Meckling (1976) argue that sufficiently high leverage creates asset-substitution or risk-shifting moral hazard: Bank managers and shareholders prefer riskier gambles to safer ones, simply out of a desire to maximize the value of their equity option on bank assets. Coping with this moral hazard requires one to limit the use of leverage unless the discipline achieved through liabilities is able to keep pace with the potential for asset substitution. So for banks, the discipline has to be particularly harsh. "Run"-able demand deposits provide just that discipline, but in general asset-substitution moral hazard can dominate the value of discipline when bank leverage is high.

This tension between the run-based disciplining role of leverage and the risk-inducing role of debt has been formally examined in a recent paper by Acharya, Mehran, and Thakor (2010), which considers a model in which creditors can incur a fixed monitoring cost to detect managerial inefficiency or fraud. ${ }^{4}$ Upon finding either, they could threaten to liquidate the bank, thereby creating a "creditor run." At the same time, however, the presence of leverage can give bank managers the opportunity to gamble and expose the bank to risky outcomes. Acharya, Mehran, and Thakor show theoretically that the bank is caught between a rock and a hard place in its choice of a privately optimal capital structure. If the bank does not choose a sufficiently high amount of leverage, then its creditors do not have enough "skin in the game" to find the investment in monitoring worthwhile. They could threaten the bank with liquidation for observed underperformance, thereby imposing the necessary market discipline. However, if the leverage ratio is too high, asset-substitution moral hazard is triggered, and the bank may be induced to take excessive risk at the creditors' expense, thereby expropriating wealth from the creditors and depositors to the benefit of the shareholders. ${ }^{5}$

Acharya, Mehran, and Thakor show that the bank's privately optimal capital structure must navigate between these two forms of moral hazard. In particular, leverage must be high enough to induce the discipline imposed by creditors, but low enough to ensure that the bank's risk taking is not excessive. This balance

\footnotetext{
${ }^{4}$ Acharya and Thakor (2010) also see an inherent conflict between the market discipline of an individual bank having a fragile capital structure and the financial stability of the system, when the fragility of an individual bank in the form of a depositor or creditor run can induce (potentially inefficient) information-based runs on other banks.

${ }^{5}$ For financial firms, this asset-substitution moral hazard takes on particular importance, as it is far easier to reallocate financing across different transactions and alter risks at a high frequency before creditors can discern the problem-in contrast to, say, an automobile company that would face immediate customer outrage were it to make riskier cars (a point referred to as the "paradox of liquidity" by Myers and Rajan [1998]). In Acharya, Mehran, and Thakor, the manager's compensation is perfectly correlated with the wealth of the initial shareholders, so the manager has the same incentive as shareholders to take risk. This is consistent with the idea that bank managers may be incentivized to take high risk because of the nature of their compensation, a sentiment reflected in the greater regulatory oversight of bank executive compensation that occurred following the recent crisis.
} 
ensures that bankers are taking economically attractive risks (such as making loans to positive net-present-value projects), but, at the same time, they are not making excessively risky bets (such as funding undercapitalized mortgages).

Since bank-level agency problems are adequately taken into account by bank-level capital structure problems, this argument does not provide a reasonable case for regulatory setting of capital requirements. Acharya, Mehran, and Thakor show, however, that the argument for a privately optimal capital structure can break down completely in the presence of regulatory distortions, which we now consider.

\section{The Role of Regulatory Safety Nets and a Step toward Robust Capital Regulation}

So far, we have deliberately excluded the role of regulatory safety nets in the bank's leverage choice. These safety nets mean that, if a bank fails, its creditors do not have to take all of the losses on their claims that they otherwise would. The bulk of a commercial bank's deposits is insured, whereas its equity is not. Deposit insurance-as well as other safety-net initiatives, such as ex post

\section{[Safety nets] help prevent a wide-scale collapse of the intermediation services provided by the banking sector and can avert various forms of contagion that could hurt the economy.}

bailouts of some failing banks — turns overnight debt financing, which would ordinarily be very risk sensitive, into financing that is more tolerant of changes in a bank's riskiness. A similar argument applies to undercapitalized over-the-counter derivatives exposures that large financial firms have to one another. ${ }^{6}$

Another financial safety net is provided by the central bank in its role as lender of last resort. Through its discount window, the central bank plays a liquidity transformation role by providing banks with access to short-term liquidity. Discount window access enables banks to turn illiquid assets (the collateral pledged) into liquid assets minus a "haircut." ${ }^{7}$ The discount window complements deposit insurance. While deposit insurance allows

\footnotetext{
${ }^{6}$ See Song and Thakor (2007), who show that deposit insurance adds to the "stickiness" of a bank's core deposits. That is, deposit insurance can induce a sort of self-selection among investors: Those who are more interested in the bank's transaction services but less able or willing to monitor the bank choose to become insured depositors, whereas the more active monitors become suppliers of uninsured (purchased) money. Consequently, core deposits, which are covered by deposit insurance, are less subject to withdrawal risk.

${ }^{7}$ We subsequently discuss the practical difficulties of distinguishing between insolvency and illiquidity.
}

banks to obtain cheaper funding and subsidizes the liability side of the balance sheet, the discount window gives banks access to short-term liquidity when the market is unwilling to provide it.

There are many ways of rationalizing these safety nets, but certainly they help prevent a wide-scale collapse of the intermediation services provided by the banking sector and can avert various forms of contagion that could hurt the economy (such as a severe recession or worse). In other words, they are part and parcel of the desire for a safe, sound, and stable banking system. Moreover, they help banks engage in effective maturity transformation: Liabilities can be of shorter maturity in the presence of deposit insurance, and assets can be of longer maturity (and hence less liquid) in the presence of the discount window. In short, there are valid economic reasons to have regulatory safety nets in banking, when viewed purely from an ex post standpoint in midcrisis.

However, it is now becoming abundantly clear-both in theory and in practice- that regulatory safety nets can come at a fairly substantial cost, not just ex post in terms of fiscal outlays (Ireland's sovereign credit risk following bank bailouts being a prime example), ${ }^{8}$ but also ex ante in terms of moral hazard. The most obvious moral hazard takes the form of banks being encouraged to become more highly levered. Because creditors do not face the same risk exposure as they would in the absence of safety nets, the credit disciplining effect discussed earlier is dampened, and the pricing of bank debt becomes relatively insensitive to the amount of leverage. As a result, leverage appears "cheap" to banks, even as they take on increasing amounts that make the bank riskier and riskier. ${ }^{9}$

The presence of the safety net-deposit insurance and the role of lender of last resort-upsets the balance of a finely tuned capital structure, as described by Acharya, Mehran, and Thakor (2010): enough equity capital to attenuate asset-substitution moral hazard, yet not so much as to water down the market discipline provided by uninsured creditors. In addition to describing this bank-specific effect, Acharya, Mehran, and Thakor argue that bank risk taking has an important collective or systemic dimension. Banks can choose to take not only excessive idiosyncratic risk, but also risk that is highly correlated

\footnotetext{
$\overline{8}$ See, for example, Acharya, Drechsler, and Schnabl (2011) for a theoretical analysis of bank bailouts in a world of limited fiscal resources and for supporting empirical evidence provided by the euro zone's sovereign credit woes.

${ }^{9}$ Merton (1977) shows that deposit insurance essentially gives the bank an option to "put" its assets to the deposit insurer in the event that the assets fall below liabilities, and that the value of this option increases as the bank's leverage goes up. The discount window has a similar effect. The availability of financing through the discount window significantly reduces the refinancing risk in maturity transformation. Moreover, as Farhi and Tirole (2009) point out, the central bank may be unable to tell whether a bank is illiquid or insolvent. This means that insolvent banks may also be able to stay alive by tapping the discount window, an action that in turn encourages banks to become more highly levered.
} 
across banks (for example, by engaging in "herding" behavior on similar asset classes for lending or investment purposes). ${ }^{10}$

If all banks choose excessive and highly correlated risks, they are likely to fail together. And faced with industrywide failures, regulators are more likely to step in and bail out banks because such an industry collapse would have potentially devastating real economic effects. ${ }^{11}$ Acharya, Mehran, and Thakor show that the mere anticipation of this forbearance when banks fail en masse may cause them to choose highly correlated, excessively risky projects. In pricing the uninsured debt, creditors will not "punish" banks ex ante for systemic risk in their portfolio choices because they - the creditors—anticipate being bailed out ex post. All

It is now becoming abundantly clear-both in theory and in practice - that regulatory safety nets can come at a fairly substantial cost, not just ex post in terms of fiscal outlays..., but also ex ante in terms of moral hazard.

market discipline of debt is lost, and banks end up choosing much higher leverage ex ante.

The channel of moral hazard is interesting. Ex post, it is the creditors of banks who get bailed out, typically not bank shareholders, but this means that, ex ante, creditors do not price the correlated risk of bank projects adequately. For bank shareholders, this situation increases the attractiveness of riskier gambles, and banks are often inclined to pursue these until the bets (almost inevitably) go bad. When this happens, the lender of last resort bails out banks, and taxpayer funds get transferred to bank creditors. Because these transfers are reflected in the ex ante pricing of debt, it is effectively an ex ante wealth transfer from taxpayers to bank shareholders, managers, and employees.

One avenue available for mitigating this correlation-induced systemic risk is through appropriate pricing of deposit insurance. Specifically, deposit insurance premiums should cover not just the expected loss (to the deposit insurance fund) for a given bank but, more important, its contribution to overall banking system risk, which is a combination of size and correlation. ${ }^{12}$ However, to

\footnotetext{
${ }_{10}$ Acharya (2009) models this collective agency problem and refers to it as "systemic risk-shifting." For supporting evidence on correlated bank exposures, see Schuermann and Stiroh (2006), who show that, among firms that make up the S\&P 500, the average equity return correlation among banks is higher than the correlation for firms in any other industry (energy firms come in second).

11 See Acharya and Yorulmazer (2007) and Farhi and Tirole (2009) for formal analyses of this time-inconsistency problem facing regulators when they have discretion over bailouts and expansionary monetary policy, respectively.

12 See, among others, Acharya, Santos, and Yorulmazer (2010) and Kuritzkes, Schuermann, and Weiner (2005).
}

the extent that some guarantees are implicit in nature, appropriate pricing of deposit insurance premiums may not suffice.

Acharya, Mehran, and Thakor argue that to prevent the "looting" of taxpayer funds (to borrow a term from Akerlof and Romer [1993]) through excessive leverage and correlated risk taking by banks, the regulator needs to impose a well-designed scheme of capital regulation that is robust in the following sense. The capital regulation must be such that the bank's leverage ratio stays below the upper bound beyond which the banks collectively wish to take excessive, correlated risks and so extract subsidies from the safety net. At the same time, creditors should not perceive banks to be so safe that they fail to discipline their asset choices through monitoring and timely pricing of credit risks. Acharya, Mehran, and Thakor propose two important measures to deal with this trade-off.

One measure is a regular core capital requirement guaranteeing that the bank's leverage never exceeds the upper bound and so keeps risk-shifting incentives in check. The other-and more innovative-measure is a "special capital account" that is built up through retained earnings made possible by restricting dividend payouts by the bank. An important purpose of this special capital account is to provide the bank with a readily available resource that can be tapped to instantaneously replenish a diminished core capital account to its desired level. In other words, an automatic and mechanical transfer from the special capital account to the core capital account would occur whenever the bank suffers an income shock that depletes the core account. Restrictions on dividend payouts are then imposed on the bank to ensure that the special capital account is rebuilt to its original level over time through retained earnings.

This special account needs to have several noteworthy features. First, the capital must be invested in predesignated liquid securities such as Treasuries in order to remove managerial discretion over the use of that capital. This action eliminates the potential moral hazard of bank managers being less efficient because they have excess cash that is not needed to run the bank. Although managers clearly have limited control rights over this capital account, it does have value that can be monetized-for instance, through the sale of the bank.

Second, the capital account accrues to the shareholders as long as the bank is solvent-for instance, it can be used to meet special capital account requirements in the next period. However, if the bank becomes insolvent and there is no industrywide rescue of banks by the lender of last resort, the capital account accrues to the regulator rather than to the bank's creditors. The idea is that, in an industrywide rescue, there is a scarcity of bank capital, and since the regulator is implicitly recapitalizing the system, the special capital account also accrues indirectly to creditors.

However, in the case of individual bank failures, the assets of these institutions can be acquired by well-capitalized players in 
the financial system. Here, the creditors can be forced to take a haircut without the system suffering substantial repercussions. ${ }^{13}$

That creditors do not benefit from the special capital account in the event of individual bank failures means that this capital is "invisible" to creditors and ensures that they have enough "skin in the game" to discipline the banks - that is, their incentives to credibly threaten withdrawal of financing and premature liquidation are not diluted by having this additional capital in the bank. Regulators would need to be explicitly directed, by regulation and law, to take possession of the special capital account in the event of bank insolvency. They could deploy the acquired capital to aid parts of the financial sector affected by the failing institution, or even to directly assist affected parts of the household and real sectors. Alternatively, this capital could be saved as a buffer against a fullblown future crisis.

Thus, our overall proposal is a form of "capital preservation," whose goal is to ensure that the probability of the bank falling into an insolvent state is minimized ex ante. But it also provides for "market discipline preservation," whose goal is to ensure that creditors have sufficient incentives to intervene in underperforming banks. ${ }^{14}$ In this way, the capital account acts as a deductible on explicit and implicit government insurance claims (prepaid by the shareholders) and serves to reduce systemwide losses given default, though not necessarily so for creditors of any particular bank.

Third, since the special capital account is built up gradually through retained earnings, the bank typically does not have to raise equity in order to satisfy its capital requirement. Furthermore, since such a transfer occurs mechanically based on marketobserved performance variables, no new information is released to the market-in contrast to a bank's voluntary issuance of equity, which reveals private information and will generally be perceived by the market as negative news. Thus, the bank is able to avoid the information costs associated with issuing equity (as in Myers and Majluf [1984]), which often make bank managers and CEOs reluctant to issue equity in the first place. Meanwhile, the bank is not put in a position of having to raise equity when it is in financial distress and doing so might be difficult or costly.

In this sense, Acharya, Mehran, and Thakor's proposal can be thought of as a mechanism to enforce countercyclical capital requirements, which have been proposed as an important part of the regulatory toolkit for macroprudential regulation of the financial sector.

\footnotetext{
${ }^{13}$ While the theoretical argument of Acharya, Mehran, and Thakor implies that too much deposit insurance may not be desirable because it compromises depositors' monitoring of banks, our proposal in practice would not pass haircuts to insured depositors.

${ }^{14}$ Note that our proposal focuses on reducing the bank's likelihood of getting into trouble rather than on improving methods for resolving bank distress, which is an important regulatory topic in itself.
}

Fourth, in the absence of a systemwide rescue, the transfer from the special capital account to the core capital account and the accompanying dividend restrictions are mechanically triggered, based on prespecified rules (linked, for example, to the financial sector's total market capitalization loss in the last year). In other words, regulators have no discretion in the matter. This way, there is no bank-specific information conveyed by these actions, and the issue of the trigger somehow becoming a self-fulfilling prophecy of failure for an individual bank would not arise. ${ }^{15}$ Also, because the special capital account is invested in Treasury securities or other cash-like instruments, the bank always has a buyer of liquid assets in the event of a liquidity crunch.

Finally, because the special capital account restricts the ability of banks to profit at the expense of taxpayers, bank shareholders would in fact be discouraged from excess leverage and correlated risk taking in the first place. Similarly, creditors would monitor the bank because additional bank capital does not buffer them against losses in times when rescues are not systemwide. Thus, the purpose of the special capital account is to give banks and their creditors the right incentives - rather than the mechanical role of buffering against future losses, which is the current approach to using bank capital under the Basel capital requirements. ${ }^{16}$

In this respect, our proposal differs from the use of contingent capital, which is a new instrument with built-in features to convert debt into equity once the bank or the system is in a state of crisis. Contingent capital is largely an ex post mechanism that attempts to deal with a paucity of equity capital in midcrisis (see, for example, Flannery [2009]), whereas our proposal is an ex ante incentive device, intended to diminish the probability of entering a crisis state in the first place. Furthermore, calibration of the two capital requirements can be made more robust by relying on multiple ways to assess the risk of bank assets (including the use of historical data, market data, regulatory stress tests, and systemic risk assessments) - thereby maintaining a buffer in the special capital account.

Would Higher Capital Requirements Hurt a Bank's Value? The capital regulation framework described in Acharya, Mehran, and Thakor (2010) is intended to inject more capital into banking and steer banks to actions that would reduce the likelihood of crises, without diluting the monitoring incentives of uninsured creditors. Opponents of higher capital requirements might object on two grounds, however.

\footnotetext{
$\overline{15}$ If the trigger is based on regulatory discretion, it will convey information to the market that the regulator knows that something is wrong. This will cause creditors to withdraw funding to the bank, precipitating the very crisis the regulator had wished to avoid.

${ }^{16}$ Of course, in practice, regulatory design of required leverage ratios may not fluctuate on a frequent or perfect basis, resulting in actual contributions to the special capital account—an issue that would require a certain amount of regulatory calibration over time.
} 
First, they would argue that equity capital is very expensive for banks in the sense that bank shareholders demand a very high return on their investment. So, asking banks to post more capital will force them to reduce the size of their balance sheets because they will be unable to find investments with sufficient rates of return to cover those demanded by shareholders on the additional equity. This reduced lending by banks, in turn, will lead to less credit creation and thus lower growth and hurt global GDP.

We can show the weakness in this argument by discussing a corollary to it: Higher leverage is preferred because it leads to a higher return on equity (ROE). Some bankers put forth this reasoning to suggest that higher capital requirements will reduce shareholder value in banking, but of course it is not so simple. True, a bank's ROE will decrease with a decline in leverage, but so

\section{Higher bank capital improves the incentives of banks to monitor their own borrowers and to develop stronger long-term relationships, an outcome that in turn generates economic value.}

too will its cost of equity capital (that is, the minimum expected rate of return demanded by shareholders to compensate for the decline in risk). So, changes in leverage would have no impact on bank value or on the size of bank balance sheets.

Moreover, this decline in leverage increases the loss-absorption buffer to debtholders who can afford to reduce their required yield, lowering the bank's cost of funds. Needless to say, with taxes, an increase in leverage causes ROE to rise faster than the bank's equity cost of capital, so shareholder value goes up, ignoring agency costs and other frictions associated with leverage. But this is nothing more than the debt-tax-shield argument, which should also apply to nonfinancial firms. The point is that if banks put more equity capital on their balance sheets, the rate of return their shareholders require will decrease, and equity will not seem nearly as expensive.

Opponents of higher capital requirements would also argue that banks will simply be worth less to their owners if those owners are forced to post more capital. After all, if deposits cost 3 percent and equity costs 20 percent, would the owners of the bank not be worse off if they were forced to fund at the margin with equity rather than deposits? Mehran and Thakor (2011) expose the theoretical fallacy of this logic, but one may argue that this is ultimately an empirical question. The empirical evidence in Mehran and Thakor shows that bank capital and bank value are actually positively correlated in the cross section of banks. ${ }^{17}$

\footnotetext{
17 Mehran and Thakor also examine the endogeneity of bank capital, and suggest that the association from bank capital to bank value is causal.
}

Chart 2

Mean Book Equity Ratios for U.S. Banks: 1893-2010

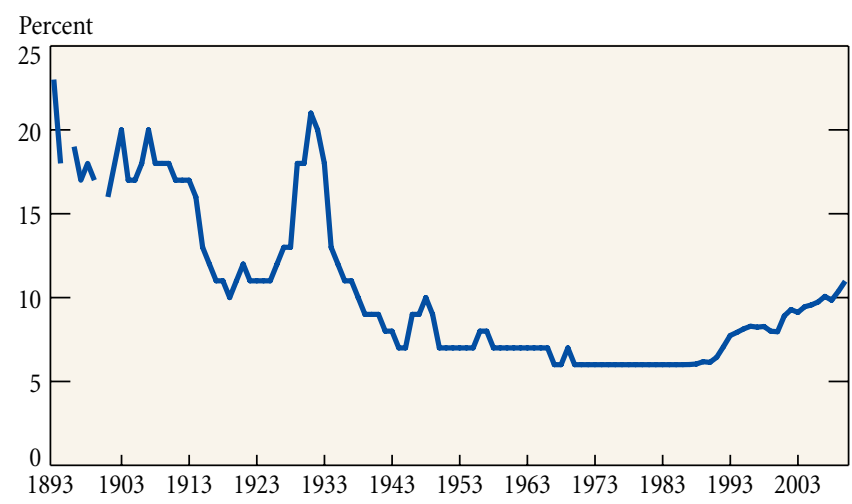

Sources: Data through 2001 are from Flannery and Rangan (2008); data since 2001 are from the Federal Reserve's Y-9C reports.

Note: Data since 2001 are average quarterly capital ratios for the 100 largest bank holding companies.

That is, banks with more equity capital:

- generate higher net present value for their shareholders (the value created for shareholders over and above what they invested in the bank is higher when the shareholders invest more capital in the bank),

- are acquired at higher prices in mergers,

- are paid more in goodwill in the acquisition price, and

- experience higher total (enterprise) values (debt plus equity).

Mehran and Thakor argue that higher bank capital is good not only for greater safety and soundness of the banking system, but also for the banks themselves. Higher bank capital improves the incentives of banks to monitor their own borrowers and to develop stronger long-term relationships, an outcome that in turn generates economic value.

\section{Calibration of Capital Requirements}

The answer to the question of how much capital banks should hold is invariably tied to the return distribution of the bank's assets, both on balance sheet (actual) as well as off balance sheet (contingent). To determine how much capital is required, one has to know how risky the assets are. Since bank balance sheets are relatively opaque (Morgan 2002), banks are especially susceptible to the "asset-substitution" problem.

Just how opaque and full of surprises bank balance sheets can be was highlighted during the recent financial crisis, with the rather slow recognition of subprime risk hidden in the plethora of complex structured credit products. The resulting uncertainty about the precise distribution of returns and contingent assets 
and liabilities introduces significant "model risk" into any regulatory calibration of bank capital requirements. ${ }^{18}$

Further, opaqueness of bank balance sheets, combined with the structural incentives for banks to benefit strategically from the opaqueness, can create more tail risk for bank asset return distributions. ${ }^{19}$ That is, these distributions are both more complex (less normal) as well as harder for outsiders to estimate, making it more difficult for debt to perform its monitoring and disciplining role. At any rate, banks are thinly capitalized compared with other industries, so the margin of error around capital adequacy needs to be quite small.

Given these considerations, which are only exacerbated by distortions introduced through access to the safety net (deposit insurance and lender of last resort), our view is that a sensible policy path is to put a premium on robustness of calibrations along two dimensions.

First, one should develop and apply several different estimates of capital adequacy and develop appropriate loss-absorption mechanisms to help address the distortions. Assessments of capital adequacy can be based on different ways of estimating asset quality and risk, such as a set of regulatory risk-weighting schemes along the lines of Basel III, plus stress tests along the lines of the SCAP, as well as market measures of systemic risk based on credit default swap spreads, equity returns, and volatility (for instance, as proposed by Acharya, Pedersen, Philippon, and Richardson [2010] and Brownlees and Engle [2010]). ${ }^{20}$ This is the "belt and suspenders" approach, which calls for some redundancy in the number of ways in which capital adequacy is assessed.

The special capital account could provide the second margin of safety in the calculation of capital adequacy - a buffer for the regulator's own model risk. This margin is necessary because opaque balance sheets, contingent exposures that are off balance sheet, and fat-tailed asset-return distributions all make it likely that calculations of the needed capital buffer will be imprecise. Moreover, the possibility of contagion and the thin capital cushions of banks make this buffer more of an imperative.

Capital ratios for banks have been increasing since their recovery from the shock of the financial crisis. Prior to the introduction of deposit insurance, bank capital ratios were quite volatile and at times very high, fluctuating between 10 percent and more

\footnotetext{
${ }^{18}$ A risk-sensitive capital regime presumes a model of riskiness of the banks' assets and activities; these are called "risk weights." Though carefully chosen, these weights could turn out to be wrong - meaning the model of bank asset riskiness could be wrong.

${ }^{19}$ See Rajan (2006) and Acharya, Cooley, Richardson, and Walter (2010).

${ }^{20}$ To be sure, only stress tests have the potential for taking systemic risks into account based on granular asset-level data. Current regulatory risk weights on assets and internal risk-weighting models do not account for systemic risk.
}

than 20 percent between the end of the nineteenth century and the Great Depression (Chart 2). The period after World War II saw capital ratios hovering steadily at around 6 percent, increasing only after the introduction of the Federal Deposit Insurance Corporation Improvement Act in 1991 (fully implemented in 1993). Currently, the debate continues over what the regulatory minimum capital ratio will be.

\section{Conclusion}

This article examines the important issue of banks' choices of privately optimal capital structures, the circumstances under which regulators would be imprudent to rely on those choices, and the optimal design of capital regulation. To that end, we also propose a novel capital framework for banks, based on Acharya, Mehran, and Thakor (2010), comprising two types of capital requirements. The first is a regular tier-one capital requirement that would help deter excessive risk-taking incentives. The second is a special capital account that would also limit risk taking, but would ensure that creditors' disciplining incentives are preserved. In particular, the special capital account would belong to the bank's shareholders when the bank is solvent, but would go to the regulators - rather than the bank's creditors-if the bank fails.

The capital requirement proposed here is robust in the sense that it could simultaneously accomplish four goals. The first is to bring more capital into banking and hence contribute to the safety and soundness of the financial sector-without necessarily requiring banks to issue new equity. The second is to improve bank incentives to reduce the probability of a crisis, rather than focusing on what to do when a crisis occurs. The third goal is to accomplish all of this without diluting the market discipline provided by uninsured debt. In this respect, our proposal differs from those that would simply infuse banks with more equity through higher minimum capital requirements. And the fourth is to do this in the simplest manner possible, using well-known instruments (equity and retained earnings to build up equity) rather than new instruments whose pricing characteristics and market impact may be hard to gauge.

\section{References}

Acharya, Viral V.2009. “A Theory of Systemic Risk and Design of Prudential Bank Regulation." Journal of Financial Stability 5, no. 3 (September): 224-55.

Acharya, Viral V., Thomas Cooley, Matthew Richardson, and Ingo Walter. 2010. "Manufacturing Tail Risk: A Perspective on the Financial Crisis of 2007-09." Foundations and Trends in Finance 4, no. 4: 247-325.

Acharya, Viral V., Itamar Drechsler, and Philipp Schnabl. 2011. "A Pyrrhic Victory? Bank Bailouts and Sovereign Credit Risk.” Unpublished paper, New York University, August.

Acharya, Viral V., Hamid Mehran, and Anjan Thakor. 2010. "Caught between Scylla and Charybdis? Regulating Bank Leverage When There Is Rent Seeking and Risk Shifting." Federal Reserve Bank of New York Staff Reports, no. 469, September; revised April 2011. 
Acharya, Viral V., Lasse Pedersen, Thomas Philippon, and Matthew Richardson. 2010. “Measuring Systemic Risk." Unpublished paper, New York University, May. Acharya, Viral V., João Santos, and Tanju Yorulmazer. 2010. “Systemic Risk and Deposit Insurance Premiums." Federal Reserve Bank of New York Economic Policy Review 16, no. 1 (August): 89-99.

Acharya, Viral V., and Anjan Thakor. 2010. “The Dark Side of Liquidity Creation: Leverage-Induced Systemic Risk and the Lender of Last Resort.” Unpublished paper, New York University.

Acharya, Viral V., and Tanju Yorulmazer. 2007. "Too Many to Fail: An Analysis of Time-Inconsistency in Bank Closure Policies.” Journal of Financial Intermediation 16, no. 1 (January): 1-31.

Admati, Anat R., Peter M. DeMarzo, Martin F. Hellwig, and Paul Pfleiderer. 2010. "Fallacies, Irrelevant Facts, and Myths in the Discussion of Capital Regulation: Why Bank Equity Is Not Expensive." Stanford University Working Paper no. 86, August. Available at http://www.gsb.stanford.edu/news/research/admati.etal.html. Akerlof, George A., and Paul M. Romer. 1993. “Looting: The Economic Underworld of Bankruptcy for Profit." Brookings Papers on Economic Activity, no. 2: 1-74.

Brownlees, Christian, and Robert Engle. 2010. "Volatility, Correlation, and Tails for Systemic Risk Measurement.” Unpublished paper, New York University, May.

Calomiris, Charles, and Charles Kahn. 1991. "The Role of Demandable Debt in Structuring Optimal Banking Arrangements.” American Economic Review 81, no. 3 (June): 497-513.

Diamond, Douglas W., and Raghuram G. Rajan. 2000. “A Theory of Bank Capital.” Journal of Finance 55, no. 6 (December): 2431-65.

-2001. "Liquidity Risk, Liquidity Creation, and Financial Fragility:

A Theory of Banking." Journal of Political Economy 109, no. 2 (April): 287-327.

Farhi, Emmanuel, and Jean Tirole. 2009. "Leverage and the Central Banker's Put." American Economic Review 99, no. 2 (May): 589-93.

Flannery, Mark J., and Kasturip P. Rangan. 2008. "What Caused the Bank Capital Build-up of the 1990s?” Review of Finance 12, no. 2: 391-429.
Jensen, Michael C., and William H. Meckling. 1976. "Theory of the Firm: Managerial Behavior, Agency Costs, and Ownership Structure." Journal of Financial Economics 3, no. 4 (October): 305-60.

Kuritzkes, Andrew, Til Schuermann, and Scott M. Weiner. 2005. “Deposit Insurance and Risk Management of the U.S. Banking System: What Is the Loss Distribution Faced by the FDIC?" Journal of Financial Services Research 27, no. 3 (September): 217-43.

Mehran, Hamid, and Anjan V. Thakor. 2011. "Bank Capital and Value in the Cross-Section." Review of Financial Studies 24, no. 4 (April): 1019-67.

Merton, Robert C. 1977. "An Analytic Derivation of the Cost of Deposit Insurance and Loan Guarantees: An Application of Modern Option Pricing Theory." Journal of Banking and Finance 1, no. 1 (June): 3-11.

Modigliani, Franco, and Merton H. Miller. 1958. "The Cost of Capital, Corporation Finance, and the Theory of Investment.” American Economic Review 48, no. 3 (June): 261-97.

Morgan, Donald P. 2002. "Rating Banks: Risk and Uncertainty in an Opaque Industry.” American Economic Review 92, no. 4 (September): 874-88.

Myers, Stewart, and Nicholas Majluf. 1984. "Corporate Financing and Investment Decisions When Firms Have Information That Investors Do Not Have." Journal of Financial Economics 13, no. 2 (June): 187-221.

Myers, Stewart, and Raghuram G. Rajan. 1998. “The Paradox of Liquidity.” Quarterly Journal of Economics 113, no. 3 (August): 733-71.

Rajan, Raghuram G. 2006. “Has Finance Made the World Riskier?” European Financial Management 12, no. 4 (September): 499-533.

Schuermann, Til, and Kevin J. Stiroh. 2006. "Visible and Hidden Risk Factors for Banks.” Federal Reserve Bank of New York Staff Reports, no. 252, May.

Song, Fenghua, and Anjan V. Thakor. 2007. "Relationship Banking, Fragility, and the Asset-Liability Matching Problem." Review of Financial Studies 20, no. 6 (November): 2129-77.

\section{ABOUT THE AUTHORS}

Viral Acharya is the C. V. Starr Professor of Economics at New York University; Hamid Mehran is an assistant vice president at the Federal Reserve Bank of New York; Til Schuermann is a partner at Oliver, Wyman \& Company; Anjan Thakor is the John E. Simon Professor of Finance at Washington University in St. Louis.

Current Issues in Economics and Finance is published by the Research and Statistics Group of the Federal Reserve Bank of New York. Linda Goldberg, Erica L. Groshen, and Thomas Klitgaard are the editors.

Editorial Staff: Valerie LaPorte, Mike De Mott, Michelle Bailer, Karen Carter, Anna Snider

Production: Carol Perlmutter, David Rosenberg, Jane Urry

Subscriptions to Current Issues are free. Send an e-mail to Research.Publications@ny.frb.org or write to the Publications Function, Federal Reserve Bank of New York, 33 Liberty Street, New York, N.Y. 10045-0001. Back issues of Current Issues are available at http://www.newyorkfed.org/research/current_issues/.

The views expressed in this article are those of the authors and do not necessarily reflect the position of the Federal Reserve Bank of New York or the Federal Reserve System.

\section{Follow us on Twitter:@NYFedResearch}




\section{Follow Us on Twitter!}

The Research Group recently launched a Twitter feed, designed to offer the first word on developments the Group, such as:

- new publications and blog posts,

- updates on economists' work and speaking engagements,

- postings of key indexes and data,

- media coverage of the Group's work, and

- other news of interest to website visitors.

\section{Follow us: @NYFedResearch}

\section{RELATED READINGS: CAPITAL REGULATION}

\section{Liberty Street Economics Blog Posts}

Available at http://libertystreeteconomics.newyorkfed.org/

Designing Executive Compensation to Curb Bank

Risk Taking

Hamid Mehran

November 30, 2011

Using Crisis Losses to Calibrate a Regulatory

Capital Buffer

Beverly Hirtle

October 24, 2011

Why Did U.S. Branches of Foreign Banks Borrow at the Discount Window during the Crisis?

Linda Goldberg and David Skeie

April 13, 2011
Why Do Central Banks Have Discount Windows?

João Santos and Stavros Peristiani

March 30, 2011

How Were the Basel 3 Minimum Capital

Requirements Calibrated?

Beverly Hirtle

March 28, 2011 


\section{Papers}

Available at http://www.newyorkfed.org/research/publication_annuals/index.html

\section{Corporate Governance of Financial Institutions}

Hamid Mehran and Lindsay Mollineaux

Staff Reports, no. 539, January 2012; revised February 2012

Mehran and Mollineaux identify the tension created by the dual demands of financial institutions to be value-maximizing entities that also serve the public interest. Their study highlights the importance of information in addressing the public's desire for banks to be safe yet innovative. Regulators can choose several approaches to increase market discipline and information production. First, they can mandate information production outside of markets through increased regulatory disclosure. Second, they can directly motivate potential producers of information by changing their incentives. Traditional approaches to bank governance may interfere with the information content of prices. Thus, the lack of transparency in the banking industry may be a symptom rather than the primary cause of bad governance. The authors provide the examples of compensation and resolution. Reforms that promote the quality of security prices through information production can improve the governance of financial institutions. Future research is needed to examine the interactions between disclosure, information, and governance.

\section{Financial Intermediary Balance Sheet Management}

Tobias Adrian and Hyun Song Shin

Staff Reports, no. 532, December 2011

Conventional discussions of balance sheet management by nonfinancial firms take the set of positive net present value (NPV) projects as given, which in turn determines the size of the firm's assets. The focus is on the composition of equity and debt in funding such assets. In contrast, the balance sheet management of financial intermediaries reveals that it is equity that behaves like the predetermined variable, and the asset size of the bank or financial intermediary is determined by the degree of leverage that is permitted by market conditions. The relative stickiness of equity reveals possible nonpecuniary benefits to bank owners so that they are reluctant to raise new equity, even during boom periods when raising equity is associated with less stigma and, hence, smaller discounts. Adrian and Shin explore the empirical evidence for both market-based financial intermediaries, such as the Wall Street investment banks, as well as the commercial bank subsidiaries of the large U.S. bank holding companies. They further explore the aggregate consequences of such behavior by the banking sector for the propagation of the financial cycle and securitization.

\section{Corporate Governance and Banks: What Have} We Learned from the Financial Crisis?

Hamid Mehran, Alan Morrison, and Joel Shapiro Staff Reports, no. 502, June 2011

Recent academic work and policy analysis give insight into the governance problems exposed by the financial crisis and suggest possible solutions. The authors begin by explaining why governance of banks differs from governance of nonfinancial firms. They then look at four areas of governance: executive compensation, boards, risk management, and market discipline. The paper discusses promising solutions and areas where further research is needed.

\section{Caught between Scylla and Charybdis? Regulating Bank Leverage When There Is Rent Seeking and Risk Shifting \\ Viral V. Acharya, Hamid Mehran, and Anjan Thakor Staff Reports, no. 469, September 2010; revised April 2011}

The authors consider a model in which banks face two moral hazard problems: 1) asset substitution by shareholders, which can occur when banks make risky, negative net-present-value loans; and 2) managerial rent seeking, the result of bank owners investing in inefficient "pet" projects or shirking in effort. The privately optimal level of bank leverage is neither too low nor too high: It efficiently balances the market discipline that owners of risky debt impose on managerial rent seeking against the asset substitution induced at high levels of leverage. However, when correlated bank failures can impose significant social costs, regulators may bail out bank creditors. Anticipation of this action generates an equilibrium in the authors' model featuring systemic risk, in which all banks choose inefficiently high leverage to fund correlated, excessively risky assets. Leverage can be reduced via a minimum equity capital requirement, which can also rule out asset substitution. But this also compromises market discipline by making bank debt too safe. Optimal capital regulation in this model setting requires that a part of bank capital be unavailable to creditors upon failure so as to retain market discipline and be made available to shareholders only contingent on good performance in order to contain risk taking. 